\title{
Risk and protective factors for sudden infant death syndrome
}

\author{
Fatores de risco e de proteção para a síndrome da morte súbita do lactente \\ Factores de riesgo y de protección para la síndrome de la muerte súbita del lactante
}

Aghata Marina de Faria Oliveira' ORCID: 0000-0002-8904-8267

Paula Rosenberg de Andrade" ORCID: 0000-0002-6521-9746

Eliana Moreira Pinheiro' ORCID: 0000-0003-1108-1080

Ariane Ferreira Machado Avelar' ORCID: 0000-0001-7479-8121

Priscila Costa' ORCID:0000-0002-2494-0510

Aline Santa Cruz Belela-Anacleto' ORCID: 0000-0001-7949-7571

'Universidade Federal de São Paulo. São Paulo, São Paulo, Brazil. "Centro Assistencial Cruz de Malta. São Paulo, São Paulo, Brazil.

How to cite this article: Oliveira AMF, Andrade PR, Pinheiro EM, Avelar AFM, Costa P, Belela-Anacleto ASC. Risk and protective factors for sudden infant death syndrome. Rev Bras Enferm. 2020;73(2):e20190458. doi: http://dx.doi.org/10.1590/0034-7167-2019-0458

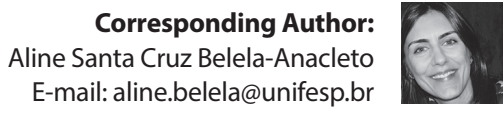

EDITOR IN CHIEF: Antonio José de Almeida Filho ASSOCIATE EDITOR: Fátima Helena Espírito Santo

Submission: 08-12-2019

Approval: 12-14-2019

\section{ABSTRACT}

Objectives: To verify the occurrence of the risk and protective factors for sudden infant death syndrome during nursing consultation. Methods: Retrospective cohort study conducted based on medical records from a primary care unit in the municipality of São Paulo. The sample consisted of 63 infants assisted from January to December 2016. Results: The average age of infants was 3.2 months. The main risk factors identified were the presence of soft objects in the crib (93.6\%) and bed sharing (58.7\%). Predominant protective factors were breastfeeding (95.2\%) followed by updated immunization (90.5\%). Conclusions: Risk and protective factors for sudden infant death syndrome were identified in the study sample, indicating the importance of addressing the issue with families of children under 1 year of age to prevent the occurrence of such events.

Descriptors: Sudden Infant Death; Risk Factors; Office Nursing; Pediatric Nursing; Child Care; Sleep.

\section{RESUMO}

Objetivos: Verificar a ocorrência de fatores de risco e de proteção para a síndrome da morte súbita do lactente durante consulta de enfermagem. Métodos: Estudo de coorte retrospectivo conduzido a partir de registros em prontuário de saúde de serviço de atenção primária do município de São Paulo. Amostra foi composta por 63 lactentes atendidos no período de janeiro a dezembro de 2016. Resultados: A média de idade dos lactentes foi de 3,2 meses. Os principais fatores de risco identificados foram presença de objetos macios no berço $(93,6 \%)$ e o compartilhamento de leito $(58,7 \%)$. Fatores de proteção predominantes foram: aleitamento materno $(95,2 \%)$ seguido de imunização atualizada $(90,5 \%)$. Conclusões: Foram identificados fatores de risco e de proteção para a síndrome da morte súbita do lactente na amostra estudada, indicando a importância da abordagem da temática junto às famílias de crianças menores de 1 ano, para prevenção da ocorrência de tais eventos. Descritores: Morte Súbita do Lactente; Fatores de Risco; Consulta de Enfermagem; Enfermagem Pediátrica; Cuidado da Criança; Sono.

\section{RESUMEN}

Objetivos: Verificar la ocurrencia de factores de riesgo y de protección para la síndrome de la muerte súbita del lactante durante consulta de enfermería. Métodos: Estudio de cohorte retrospectivo conducido a partir de registros en prontuario de salud de servicio de atención primaria del municipio de São Paulo. La muestra ha sido compuesta por 63 lactantes atendidos en el período de enero a diciembre de 2016. Resultados: La media de edad de los lactantes ha sido de 3,2 meses. Los principales factores de riesgo identificados han sido la presencia de objetos blandos/suaves en la cuna $(93,6 \%)$ y el compartir de lecho $(58,7 \%)$. Factores de protección predominantes han sido: amamantamiento materno $(95,2 \%)$ seguido de inmunización actualizada $(90,5 \%)$. Conclusiones: Han sido identificados factores de riesgo y de protección para la síndrome de la muerte súbita del lactante en la muestra estudiada, indicando la importancia del abordaje de la temática junto a las familias de niños menores de 1 año, para prevención de la ocurrencia de tales eventos.

Descriptores: Muerte Súbita del Lactante; Factores de Riesgo; Consulta de Enfermería; Enfermería Pediátrica; Cuidado del Niño; Sueño. 


\section{INTRODUCTION}

From the perspective of comprehensive child health care, the primary care level organizes childcare nursing consultation aiming to provide systematic assistance and to contribute to the promotion, protection, recovery, and rehabilitation of child and family health ${ }^{(1)}$.In this context, considering the current priority of protection and health care actions in early childhood and the concept of essential needs of children as a reference for care, the importance of approaching sleep protection as a focus of the clinical practice of nurses is emphasized ${ }^{(2-3)}$.

During the first 12 months of life, the child spends more than half the time sleeping, and sleep is not merely a resting condition, but a state that involves intense brain activity and is directly related to cognitive, psychomotor and mood development of the child ${ }^{(4)}$.

Although essential for human life and especially fundamental for child development, some sleep habits are characterized in the first year of life as risk factors for the occurrence of sudden infant death syndrome (SIDS), a condition of significant impact on children mortality indicators in developed countries. In the United States of America, it represents the leading cause of death in children aged 1 to 12 months. In developing countries and regions of great racial miscegenation, research on the subject is still scarce, as are estimates of occurrence ${ }^{(5-6)}$.

SIDS is defined as the sudden death of infants under 1 year of age with no established cause after a thorough investigation of the clinical history, analysis of the death scene and circumstances, and post-mortem examination. Currently, it is considered to have a multifactorial origin and occurs when there is a vulnerable infant in a period of critical but unstable development regarding homeostatic control (the period of most considerable risk is 2 to 4 months, with $90 \%$ of cases occurring before six months), and experiencing an exogenous stressor ${ }^{(5)}$. These stressors represent the various risk factors associated with this occurrence, such as prone sleeping position, bed sharing, surfaces and use of soft objects in the crib, overheating, smoking, low socioeconomic and educational attainment of the families, maternal age below 20 years. , single-parent families, among others ${ }^{(5-7)}$.

Given the vulnerability of a large portion of the Brazilian population assisted in public health services, characteristics similar to those described are frequently observed in nursing care practice at the primary care level.

Over the past 20 years, the promotion of healthy and safe sleep in children has become a topic of growing interest in the international scientific literature, given its crucial impact on various aspects of child health and development. National and international organizations advocate recommendations to promote a healthy and safe sleep environment for children and to prevent sleep disorders and reduce the risk of death from causes related to them ${ }^{(6-10)}$. However, studies on the sleep habits of the population in developing countries and unfavorable social groups are scarce, especially in certain age groups such as the first year of life ${ }^{(6)}$.

Considering the importance of sleep as a necessity of childhood, the possible risks related to sleeping habits, the scarcity of studies on the theme at national level, the fundamental role of nurses in the promotion of child health and the authors' experience in childcare nursing consultations, we sought to investigate the occurrence of risk and protective factors for SIDS in order to support prevention strategies.

\section{OBJECTIVES}

To verify the occurrence of the risk and protective factors for sudden infant death syndrome during nursing consultation.

\section{METHODS}

\section{Ethical aspects}

The director of the health care center authorized this study, and the Research Ethics Committee of the institution of the study approved it. Before starting data collection in the medical records, we obtained the signatures of the Free and Informed Consent Form from the families or guardians of the children.

\section{Study Design, location, and period}

A cohort study with a quantitative approach, with retrospective data collection, conducted at the outpatient clinic of a health care center.

The philanthropic institution, located in the city of São Paulo, in an area characterized by a high index of social vulnerability, has an operating structure equivalent to a Basic Health Unit and provides priority care to children, adolescents, and women, with emphasis on health promotion actions.

The childcare nursing consultation was implemented at the institution's outpatient clinic about 30 years ago. In the first year of life, all children are evaluated monthly in all aspects of health, including sleep habits. About 10 to 15 consultations are performed per week, conducted by the nurse of the service, doctor, and specialist in pediatric nursing, nurses attending the residency in neonatal nursing, and specialists in pediatric nursing of a public university that works at the institution. The consultation is made by appointment, without limitation of the family's territorial area of residence.

We obtained the data from medical records and collected it using an instrument that contemplated the study variables, which was specifically elaborated for this research.

\section{Study sample}

The sample consisted of children under 1 year of age assisted at a nursing consultation. The study included infants treated from January to December 2016, regardless of the frequency of consultations. The choice of this year as an inclusion criterion is justified because it is the year the institution implemented a new structured form to conduct the nursing consultation at the service. This instrument supports the nurse in conducting the health interview with families and addresses the characteristics of the child's sleep, as well as other social and demographic aspects. The exclusion criterion was the absence of records in the form of the researched variables.

\section{Study Variables}

Selected variables included information on infant and family characterization, as well as risk and protective factors for sudden infant death syndrome described in the literature ${ }^{(5,7,11)}$. Because the infant may have been attended more than once from January to December 2016, risk and protective factor records were 
categorized as "present at least once" or "never" during health monitoring over the 12 months. Therefore, data collection regarding the study variables occurred considering all nursing consultations of the infant throughout 2016.

Infant characterization variables included gender and age in completed months. Regarding family characterization, the following variables were included: parental marital status, maternal age and educational level, family composition, monthly family income, prenatal care or not, and the number of prenatal consultations.

The risk factors for sudden infant death syndrome described in the literature ${ }^{(5,7,11)}$ and considered in this study were: maternal age below 20 years, single-parent family, low maternal education (complete or incomplete), family income less than one minimum wage, prone infant position, sleeping bed-sharing between the child and family members, presence of soft objects in the crib and parental smoking. The protective factors for the sudden infant death syndrome were: breastfeeding, pacifier use, and updated immunization.

\section{Results analysis and statistics}

Data were tabulated in a Microsoft ${ }^{\circledR}$ Excel spreadsheet and analyzed using Epi Info 7 software. Categorical variables are presented according to absolute and relative frequencies; and numerical variables, according to descriptive statistics. In the bivariate analysis, Fisher's exact test was performed for categorical variables, considering the significance level of $\geq 5 \%$ and a $95 \%$ confidence interval.

\section{RESULTS}

Sixty-three infants who were assisted at 174 nursing appointments participated in the study. The mean age of the infants was 3.2 months, with a minimum of 7 days and a maximum of 12 months. The average age of mothers was 25 years (minimum 14 years; maximum 40 years). Most mothers ( $n=41 ; 65.1 \%)$ started prenatal care in the first trimester of pregnancy and had an average of 7.2 ( \pm 0.7 ) consultations. Table 1 presents the other sociodemographic characteristics of infants and their families.

Table 2 presents the protective and risk factors for SIDS.

Breastfeeding and updated immunization were present in more than $90 \%$ of infants treated in 2016 . The most common risk factors were the presence of soft objects in the crib and bed-sharing. As for the objects in the crib, we identified the presence of blankets ( $n=47 ; 74 \%)$, pillows $(n=42 ; 66.6 \%)$, cradle protectors $(n=17$; $26.9 \%)$, and cloth doll or teddy bear $(n=3 ; 4.7 \%)$.

Table 3 presents the analysis of the association between the sociodemographic risk characteristics of infants and their families and the presence of at least one risk factor for SIDS. The occurrence of the risk factor was not associated with the mother's age or education, parents' marital status, infant's gender, or family income.

\section{DISCUSSION}

Our findings demonstrated the incidence of protective factors in the studied population, especially breastfeeding and updated immunization, verified in most infants attended at a nursing consultation. However, we observed that most of the infants treated were exposed to at least one risk factor during the first year of life. Some identified risk factors were related to modifiable behaviors, such as placing the infant to sleep in the prone position and using soft objects in the crib.

Table 1 - Sociodemographic characteristics of infants and their families, São Paulo, São Paulo, Brazil, 2016

\begin{tabular}{lcc}
\hline Sociodemographic characteristics & $\mathbf{n}$ & $\%$ \\
\hline Infants & & \\
Males & 33 & 52.3 \\
Maternal education & & \\
Primary school & & \\
$\quad$ Complete & 8 & 12.7 \\
Incomplete & 8 & 12.7 \\
Secondary education & & \\
Complete & 21 & 33.3 \\
Incomplete & 20 & 31.7 \\
Incomplete higher education & 3 & 4.8 \\
No information provided & 3 & 4.8 \\
Family income & & \\
$\quad<$ minimum wage & 5 & 7.9 \\
$\quad \geq$ minimum wage $<2$ minimum wages & 14 & 22.2 \\
$\quad \geq 2$ minimum wages \&lt; 3 minimum wages & 19 & 30.1 \\
$\quad \geq 3$ minimum wages < 4 minimum wages & 11 & 17.5 \\
$\quad \geq 4$ minimum wages & 3 & 4.8 \\
$\quad$ No information provided & 11 & 17.5 \\
Marital status of the child's parents & & \\
Live together (married or stable union) & 51 & 80.9 \\
Single & 7 & 11.1 \\
Separated or divorced & 3 & 4.8 \\
No information provided & 2.17 \\
\hline
\end{tabular}

Table 2 - Risk and protective factors for sudden infant death syndrome identified during nursing consultation, São Paulo, São Paulo, Brazil, 2016

\begin{tabular}{lcc}
\hline & $\mathbf{n}$ & $\%$ \\
\hline Protective factors & & \\
$\quad$ Breastfeeding & 60 & 95.2 \\
Updated Immunization & 57 & 90.5 \\
Pacifier use & 35 & 55.5 \\
Risk factors & & \\
Soft objects in the crib & 59 & 93.6 \\
Bed Sharing & 37 & 58.7 \\
Parental Smoking & 17 & 27.0 \\
Low maternal education & 16 & 25.4 \\
Maternal age under 20 years & 15 & 23.8 \\
Prone sleeping position & 14 & 22.2 \\
Single parent family & 10 & 15.9 \\
Family income <1 minimum wage & 5 & 7.9 \\
\hline
\end{tabular}

Regarding the identified protective factors, several studies describe breastfeeding ${ }^{(5,7)}$ as a factor related to a lower incidence of SIDS, and this association is even more evident in cases of exclusive breastfeeding. It is noteworthy that the beneficial effect of breastfeeding has not yet been fully clarified. The most 
accepted explanation relates to the increased risk of SIDS to the occurrence of viral infections, and breastfeeding has a protective action against some infectious processes ${ }^{(5)}$. Another hypothesis is that breastfed infants awaken more easily when compared to those who use other types of milk ${ }^{(11)}$, a characteristic attributed to changes in the brain neurochemical composition of breastfed infants, especially a higher amount of long-chain fatty acids, present in breast milk.

Table 3 - Association between the sociodemographic risk characteristics of infants and their families and the occurrence of at least one risk factor for sudden infant death syndrome. São Paulo, São Paulo, Brazil, 2016

\begin{tabular}{lccc}
\hline $\begin{array}{l}\text { Sociodemographic } \\
\text { characteristics of risk }\end{array}$ & \multicolumn{2}{c}{ Risk factor for SIDS } & $\begin{array}{c}\boldsymbol{p} \\
\text { value }\end{array}$ \\
\hline Yes (n= 64) & No (n= 5) & \\
\hline Mother's age <20 years & $5(83.3 \%)$ & $1(16.7 \%)$ & 0.40 \\
Single parent family & $10(100 \%)$ & $-(0 \%)$ & 0.39 \\
low schooling & $15(93.7 \%)$ & $1(6.3 \%)$ & 0.48 \\
Males & $29(90.6 \%)$ & $3(9.4 \%)$ & 0.31 \\
Family income <1 minimum wage & $5(100 \%)$ & - & 0.65 \\
\hline
\end{tabular}

Regarding immunization, Brazil is internationally recognized as one of the countries with the highest rates of immunization coverage in children under 1 year of age, which characterizes the cultural acceptance of the procedure and justifies the identified result ${ }^{(12)}$. A meta-analysis derived from nine case-control studies concluded that immunization might halve the risk of sudden infant death. Although the authors report some methodological limitations due to the heterogeneity of the studies, they emphasize that immunization should be part of SIDS prevention campaigns, in line with international recommendations ${ }^{(13)}$. American research that aimed to analyze the association between diphtheria, tetanus, and pertussis (DTP) immunization and SIDS found specific immunization coverage to be related to lower mortality rates from SIDS ${ }^{(14)}$.

The use of pacifiers, controversial in our society, was present in more than half of the cases. The available literature reveals substantial evidence of the association between breastfeeding, pacifier use, and reduced risk of SIDS ${ }^{(11)}$. Among the mechanisms related to the protective effect, studies suggest a higher frequency of awakenings, mechanical action due to suction, and greater autonomic control $^{(5,11)}$. Studies refer to the use of pacifiers at the beginning of sleep as protective, even if the child releases it when falling asleep. For infants fed with formula or whole milk, it is possible to introduce a pacifier as soon as desired. Due to concern about interference with exclusive breastfeeding, the introduction of a pacifier for breastfed infants should be delayed until breastfeeding has been well established, which usually occurs in infants at two weeks ${ }^{(3,6)}$. This fact corroborates the ninth of the ten steps to successful breastfeeding ${ }^{(15)}$ by the World Health Organization and the United Nations Fund, which consists of counseling mothers about the use and risks of feeding bottles, teats, and pacifiers.

Regarding the risk factors for SIDS, the study shows that a significant portion of children was exposed to the presence of soft objects in the crib and bed-sharing with family members during the first year of life, results similar to those of other researches on the topic ${ }^{(5-7,16)}$.

In the United States, almost 55\% of infants sleep with thick blankets, bedspreads, and pillows, which is more prevalent among teenage mothers, families belonging to minority racial groups and those without higher education(7). Considering that a large percentage of children who die from SIDS are found with their heads covered with bedding, it is recommended that objects that can cause suffocation or strangulation - such as pillows, pillow-like toys, quilts, comforters, and loose bedding - be kept away from where the child sleeps ${ }^{(7)}$.

In a study ${ }^{(6)}$ on sleep habits of infants in the city of Passo Fundo, Rio Grande do Sul identified bed-sharing in $44 \%$ of cases, and the use of pillows in the crib was frequent. In a US national survey, there was an increasing tendency to bed-sharing from 1993 (6.5\%) to 2010 (13.5\%), and more than half (54\%) of participants did not receive information from health professionals about the risks related to the habit ${ }^{(16)}$.

In case-control studies, sharing the bed is associated with higher rates of SIDS, being related to the soft surface, the possibility of overheating, and overlapping of the child. These studies argue that the risks are even higher when sharing is associated with the following characteristics: prematurity or low birth weight; age less than 11 weeks; smoking parents; smoking mother during pregnancy; alcohol intake, use of drugs or drugs that cause drowsiness; use of sofa, armchairs or other surfaces other than the bed; and sharing all night long ${ }^{(5,7)}$. At the same time, sleeping in a parent's room, but on a separate surface, reduces the risk of SIDS by up to $50 \%$. Therefore, studies recommend that the infant share the room with the parents and sleep on a separate surface near the bed, ideally in the first year of life, but mainly until 6 months of age $\mathrm{e}^{(5,7)}$.

Despite the evidence and recommendations, bed-sharing remains a controversial issue as it may favor breastfeeding, which in turn can be a protective factor against SIDS. Also, it is known that this habit is more common in some populations for cultural reasons, low socioeconomic conditions, and space constraints at home ${ }^{(7)}$. Our findings corroborate the literature since the living conditions of the studied population include insufficient physical space for parents to accommodate the infant in their dormitory. Added to this is the vulnerability related to the other verified risk factors for SIDS, including mothers with low education, maternal age under 20 years, and single-parent families headed by women.

As for the other modifiable risk factors identified in this study, such as parental smoking and the adoption of a prone sleeping position, we emphasize the importance of nurses contributing to the dissemination of evidence-based recommendations ${ }^{(5,7)}$. The American Academy of Pediatrics ${ }^{(7)}$ recommends placing infants in the supine position to sleep until they are 1 year old to reduce the risk of SIDS. The lateral decubitus is neither safe nor advised, and the risks of prone and lateral positions are described as similar. It is noteworthy that the supine position does not increase the risk of aspiration or suffocation since children have anatomy and physiological mechanisms of protection. The ventral position should be considered only in cases of upper airway abnormalities and disorders in which the risk of death from gastroesophageal reflux exceeds the risk of SIDS. When infants acquire the ability to roll and turn over in bed, they should be left in the position they naturally adopt. Additional indications for preventing SIDS include avoiding exposure to tobacco, alcohol, and illicit drugs and should be part of the child and family health education process ${ }^{(5,7)}$. 


\section{Study Limitations}

Limitations of the research are convenience sampling, its unicentric character, and data collection from medical records.

\section{Contributions to nursing}

The presented data contribute with information about the Brazilian reality in the face of scarce studies about the theme in the national scientific literature. Additionally, the study provides essential support for addressing sleep in nursing care to children and families, especially at the primary care level. Considering that SIDS is a preventable problem, sharing knowledge with the population about protective and risk factors is paramount. In their role as educators, the primary objective of the nurses is to prevent and minimize injuries, and should, therefore, establish intervention strategies to promote healthy and safe sleep. Health education is a strategy that favors the understanding of those responsible for children about SIDS. Strengthening families in child care should involve knowledge about risk factors and effective forms of prevention, especially bed-sharing and non-use of soft objects in the crib.

Since infants may die suddenly, there is a need for widespread dissemination in society about SIDS prevention strategies through health policies and programs, as well as the involvement of health care professionals.

\section{CONCLUSIONS}

In the sample studied, breastfeeding and updated immunization were the protective factors of SIDS most commonly found in nursing consultations, and the presence of objects in the crib and bed-sharing represented the most frequent risk factors.

\section{ACKNOWLEDGMENT}

To Cruz de Malta Center Care.

\section{REFERENCES}

1. Campos RMC, Ribeiro CA, Silva CV, Saparolli. Nursing consultation in child care: the experience of nurses in the Family Health Strategy. Rev Esc Enferm USP. 2011;45(3):566-74. doi: 10.1590/S0080-62342011000300003

2. Veríssimo MDLOR. The irreducible needs of children for development: a frame of reference to health care. Rev Esc Enferm USP. 2017;51:e03283. doi: 10.1590/S1980-220X2017017403283

3. Ministério da Saúde (BR). Política Nacional de Atenção Integral à Saúde da Criança: orientações para implementação [Internet]. Brasília (DF): Secretaria de Atenção à Saúde; Departamento de Ações Programáticas Estratégicas;2018 [cited 5 Jun 2019]. Available from: http://www. saude.pr.gov.br/arquivos/File/Politica_Nacional_de_Atencao_Integral_a_Saude_da_Crianca_PNAISC.pdf

4. Ednick M, Cohen AP, McPhail GL, Beebe D, Simakajornboon N, Amin RS. A review of the effects of sleep during the first year of life on cognitive, psychomotor, and temperament development. Sleep. 2009;32(11):1449-1458. DOI:10.1093/sleep/32.11.1449

5. Carlin RF, Moon RY. Risk factors, protective factors, and current recommendations to reduce sudden infant death syndrome. A review. JAMA Pediatr. 2017;171(2):175-80. doi: 10.1001/jamapediatrics.2016.3345

6. Geib LTC, Nunes ML. Hábitos de sono relacionados à síndrome da morte súbita do lactente: estudo populacional. Cad. Saúde Pública. 2006;22(2):415-23. doi: 10.1590/S0102-311X2006000200019

7. AAP TASK FORCE ON SUDDEN INFANT DEATH SYNDROME. SIDS and Other Sleep-Related Infant Deaths: Updated 2016 Recommendations for a Safe Infant Sleeping Environment. Pediatrics. 2016;138(5):e20162938 doi: 10.1542/peds.2016-2940

8. Braig S, Urschitz MS, Rothenbacher D, Genuneit J. Changes in children's sleep domains between 2 and 3 years of age: the UIm SPATZ Health Study. Sleep Medicine. 2017;36:18-22. doi: 10.1016/j.sleep.2017.04.011

9. Buysse DJ. Sleep health: can we define it? Does it matter? SLEEP 2014;37(1):9-17. doi: 10.5665/sleep.3298

10. Hauck FR, Herman SM, Donovan M, lyasu S, Moore CM, Donoghue E, et al. Sleep Environment and the Risk of Sudden Infant Death Syndrome in an Urban Population: The Chicago Infant Mortality Study. Pediatrics. 2003;111:1207-14.

11. Alm B, Wennergren G, Moollborg P, Lagercrantz H. Breastfeeding and dummy use have a protective effect on sudden infant death syndrome. Reducing sudden infant death syndrome. Acta Pædiatrica. 2016;105(1):31-8. doi: 10.1111/apa.13124

12. Barreto ML, Teixeira MG, Bastos FI, Ximenes RAA, Barata RB, Rodrigues LC. Successes and failures in the control of infectious diseases in Brazil: social and environmental context, policies, interventions, and research needs. Lancet. May, 2011;377(9780): 1877-89. doi: 10.1016/ S0140-6736(11)60202-X

13. Vennemann MM, Höffgen M, Bajanowski T, Hense HW, Mitchell EA. Do immunisations reduce the risk for SIDS? a meta-analysis. Vaccine. 2007;25(26):4875-9. doi: 10.1016/j.vaccine.2007.02.077

14. Müller-Nordhorn J, Hettler-Chen CM, Keil T, Muckelbauer R. Association between sudden infant death syndrome and diphtheria-tetanuspertussis immunization: an ecological study. BMC Pediatr. 2015;15:1. doi: 10.1186/s12887-015-0318-7

15. World Health Organization. Ten steps to successful breastfeeding (revised 2018) [Internet]. Geneva (Switzerland): Department of Nutrition for Health and Development, World Health Organization;2018 [cited 05 Jun 2019]. Available from: https://www.who.int/nutrition/bfhi/ten-steps/en/

16. Lambert ABE, Parks SE, Shapiro-Mendoza CK. National and state trends in sudden unexpected infant death: 1990-2015. Pediatrics. 2018;141(3):e20173519. doi: 10.1542/peds.2017-3519 